\title{
REGIONÁLIS ÉGHAJLATMODELLEZÉS A WRF MODELL SEGÍTSÉGÉVEL - ÉRZÉKENYSÉGVIZSGÁLAT
}

\author{
Varga Ákos János, Breuer Hajnalka
}

ELTE Meteorológiai Tanszék, 1117 Budapest, Pázmány Péter sétány 1/A

e-mail: v.akos94@gmail.com, bhajni@nimbus.elte.hu

\section{Bevezetés}

A regionális éghajlati modellek előnye a $\mathrm{GCM}^{1}$-ekhez képest, hogy sokkal finomabb horizontális felbontás érhető el velük. Kisebb rácstávolság mellett lehetőség nyílik olyan lokális klímamódosító tényezők figyelembe vételére, mint a domborzat vagy a felszínhasználat (Rummukainen, 2010). Ezért a GCM-be ágyazott (vagy globális reanalízis által „,meghajtott”) $\mathrm{RCM}^{2}$-ek futtatása, az ún. dinamikai leskálázási eljárás, jelentős többletinformációt nyújthat egy adott térség klimatikus viszonyairól, mint a globális modellek.

Magyarországon eddig négy modellt adaptáltak regionális éghajlati szimulációk készítésének céljából: az Eötvös Loránd Tudományegyetemen a PRECIS-t és a RegCM-et, az Országos Meteorológiai Szolgálatnál pedig az ALADIN-Climate-et és a REMO-t (Krüzselyi et al., 2011). Ugyanakkor míg - a Kárpát-medencére vonatkozó projekciók alapján - a jövőben várható hőmérséklet-emelkedés tekintetében egybehangzóak a várakozások, addig a csapadékviszonyok változásának terén nagy a bizonytalanság.

A tavalyi év folyamán megkezdtük a $\mathrm{WRF}^{3}$ (Skamarock et al., 2008) modell adaptációját regionális éghajlati szimulációk készítésének céljából, különösen a csapadék várható tendenciáit övező bizonytalanság kiküszöbölésének érdekében. A WRF egyik előnye, hogy a számos beépített parametrizációs sémának, illetve a beállítások egyszerü módosíthatóságának köszönhetően széleskörü tesztelési lehetőséget nyújt felhasználói számára. A megfelelő modellkonfiguráció kiválasztása alapvetően fontos az eredmények pontosságának szempontjából. Ebben a tanulmányban bemutatjuk, hogy a WRF, mint nem-hidrosztatikus RCM, mennyire hatékonyan képes egy rövid, egy évig tartó időszak időjárási viszonyait szimulálni. A modell érzékenységét vizsgáltuk a különböző parametrizáció-kombinációkra, továbbá a futtatásokat $50 \mathrm{~km}$-es és $10 \mathrm{~km}$-es horizontális felbontással is elvégeztük, a rácstávolság hatásának megállapítására. A validációs folyamat során a modelleredményeket egy mérési adatbázissal vetettük össze. A fentebb említett okokból a klimatológiai paraméterek közül a csapadékra koncentrálunk.

\section{Modellbeállítások és futtatások}

Kísérleteinkhez a WRF-ARW ${ }^{4}$ v3.8 mezoskálájú modellt használtuk, melyet föleg kutatási célokra fejlesztettek ki az Amerikai Egyesült Államokban. A modellezési tartomány két (ún. nesting technikával) egymásba ágyazott területből áll (1. ábra). A külső tartomány (domain) $50 \mathrm{~km}$-es horizontális felbontású, lefedi a MED-CORDEX nemzetközi projekt keretében meghatározott szimulációs régiót, így a későbbiekben akár a modelleredmények összehasonlítására is lehetőség nyílhat. Tartalmazza Nyugat-, Közép- és Kelet-Európát, Afrika leg-

\footnotetext{
${ }^{1}$ General Circulation Model - általános cirkulációs modell

${ }^{2}$ Regional Climate Model - regionális éghajlati modell

${ }^{3}$ Weather Research and Forecasting Model

${ }^{4}$ Advanced Research WRF
} 
északabbi vidékeit, valamint Nyugat-Ázsia egyes országait. A belső domain rácstávolsága 10 km-es, és magában foglalja a Kárpát-medencét, az Alpok és a Kárpátok hegyvonulatait, valamint a Dinári-hegységet. Mindkét domain esetében 44 vertikális szintet használtunk. Az eredmények kiértékelése során a számításokat nagyjából az é. sz. $42^{\circ}-52^{\circ}$, valamint a k. h. $4^{\circ}-30^{\circ}$ közé eső területre végeztük el.

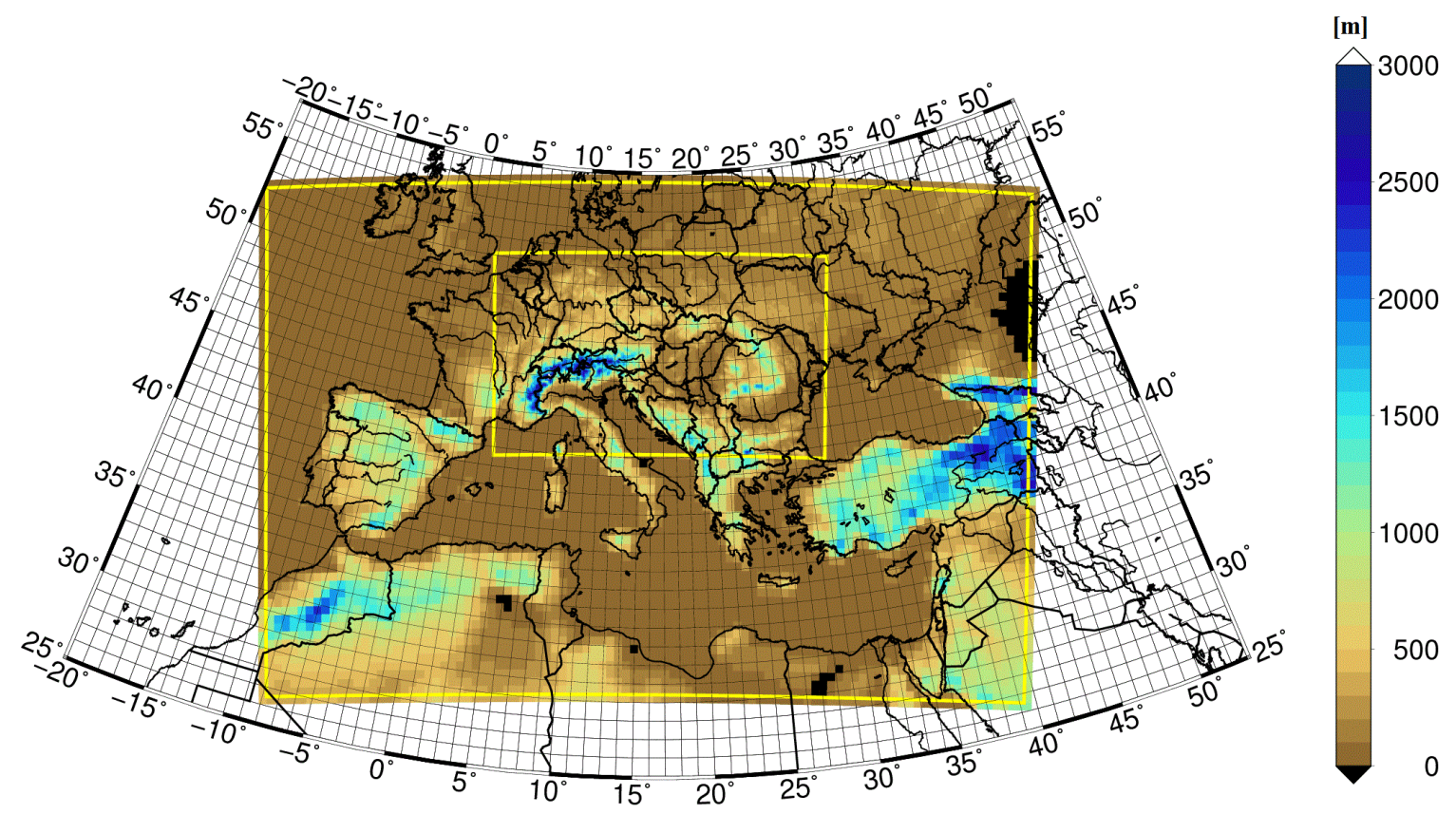

1. ábra: A két egymásba ágyazott modelltartomány és azok topográfiája a tengerszint feletti magasság értékeivel.

Vizsgálataink során öt különböző beállítással futtattuk a WRF modellt a 2013-as évre (1. táblázat). Az egyes szimulációk a mély-konvekciós (cumulus), valamint a planetáris határréteg és a felszíni réteg parametrizációjának tekintetében tértek el egymástól. A többi sémát mind az öt konfiguráció esetében változatlanul hagytuk, továbbá az összes futtatás nemhidrosztatikus módban készült.

A felhö- és csapadékképződéshez kapcsolódó mikrofizikai folyamatokat a Thompson \& Eidhammer (2014) által részletezett parametrizáció alapján vettük figyelembe, amely a korábbi Thompson mikrofizikai séma aeroszolok hatásával kiegészített változata. A rövidhullámú sugárzásátvitel Dudhia (1989) parametrizációja szerint került reprezentálásra, míg a hosszúhullámú sugárzási viszonyok képviseletére az ún. $\mathrm{RRTM}^{5}$ gyors sugárzásátviteli modellt alkalmaztuk (Mlawer et al., 1997). A felszín és a légkör közötti kölcsönhatások leírására a Noah közösségi modell ún. multiparametrizációs változatát használtuk (Niu et al., 2011).

Futtatásainkban három mély-konvekciós (cumulus) parametrizációval kísérleteztünk: a tömegfluxus elvü $\mathrm{KF}^{6}$ (Kain, 2004) és G3DE (Grell \& Dévényi, 2002), illetve a konvektív stabilizációs $\mathrm{BMJ}^{8}$ (Janjić, 1994) sémával. Az érzékenységvizsgálat során továbbá a planetáris határréteg és a hozzá tartozó felszínközeli réteg parametrizációk közül kettőt teszteltünk: a Yonsei Egyetemen kifejlesztett YSU ${ }^{9}$ sémát (Hong \& Dudhia, 2006) az MM5 ${ }^{10}$ hasonlósági

\footnotetext{
${ }^{5}$ Rapid Radiative Transfer Model

${ }^{6}$ Kain-Fritsch mély-konvekciós séma

${ }^{7}$ Grell 3D Ensemble mély-konvekciós séma

${ }^{8}$ Betts-Miller-Janjić mély-konvekciós séma

${ }^{9}$ Yonsei University planetáris határréteg séma

${ }^{10}$ Fifth-Generation Penn State/NCAR Mesoscale Model - ötödik generációs mezoskálájú modell
} 
sémával (Paulson, 1970) kombinálva, valamint az MYJ ${ }^{11}$ határréteg sémát az Eta hasonlósági elven alapuló felszínközeli réteg parametrizációval párosítva (Janjić, 1994).

A szimulációt 2013. január 1. 00 UTC időponttal indítottuk és futtattuk a modellt 1 éves időtartamra. Az oldalsó peremfeltételek 6 óránként frissültek, a felszíni adatok közül csak tengerfelszín hőmérséklete frissült ugyanilyen időközökkel.

1. táblázat: Az öt modellfuttatás során használt fizikai parametrizációs sémák.

\begin{tabular}{|c|c|c|c|c|c|}
\hline Futtatás & $\begin{array}{l}\text { Planetáris } \\
\text { határréteg, } \\
\text { felszín }\end{array}$ & $\begin{array}{l}\text { Mély-konvekció } \\
\text { (cumulus) }\end{array}$ & Mikrofizika & Sugárzásátvitel & Felszín-légkör \\
\hline YSU/KF & $\begin{array}{l}\text { YSU, MM5 } \\
\text { hasonlósági }\end{array}$ & KF & $\begin{array}{l}\text { Aeroszol-követö } \\
\text { Thompson }\end{array}$ & $\begin{array}{l}\text { Dudhia RH, } \\
\text { RRTM HH }\end{array}$ & Noah-MP \\
\hline YSU/BMJ & $\begin{array}{l}\text { YSU, MM5 } \\
\text { hasonlósági }\end{array}$ & BMJ & $\begin{array}{c}\text { Aeroszol-követő } \\
\text { Thompson }\end{array}$ & $\begin{array}{l}\text { Dudhia RH, } \\
\text { RRTM HH }\end{array}$ & Noah-MP \\
\hline YSU/G3DE & $\begin{array}{l}\text { YSU, MM5 } \\
\text { hasonlósági }\end{array}$ & G3DE & $\begin{array}{c}\text { Aeroszol-követő } \\
\text { Thompson }\end{array}$ & $\begin{array}{l}\text { Dudhia RH, } \\
\text { RRTM HH }\end{array}$ & Noah-MP \\
\hline MYJ/BMJ & $\begin{array}{l}\text { MYJ, Eta } \\
\text { hasonlósági }\end{array}$ & BMJ & $\begin{array}{c}\text { Aeroszol-követő } \\
\text { Thompson }\end{array}$ & $\begin{array}{l}\text { Dudhia RH, } \\
\text { RRTM HH }\end{array}$ & Noah-MP \\
\hline MYJ/G3DE & $\begin{array}{l}\text { MYJ, Eta } \\
\text { hasonlósági }\end{array}$ & G3DE & $\begin{array}{c}\text { Aeroszol-követö } \\
\text { Thompson }\end{array}$ & $\begin{array}{l}\text { Dudhia RH, } \\
\text { RRTM HH }\end{array}$ & Noah-MP \\
\hline
\end{tabular}

\section{Adatok}

A WRF számára a bemeneti adatokat az ECMWF ${ }^{12}$ által készített, egyelöre csak részben elérhetö ERA5 globális reanalízis adatbázisból (Hersbach \& Dee, 2016) származtattuk, melynek horizontális felbontása nagyjából $30 \mathrm{~km} \times 30 \mathrm{~km}$-es. A kezdeti- és peremfeltételek a modellben 6 óránként frissültek. A validáció során az eredményeket az E-OBS (v17.0) rácsra rendezett mérési adatbázissal vetettük össze (Haylock et al., 2008), melynek rácstávolsága $25 \mathrm{~km}$-es és napi adatokat tartalmaz. Az összehasonlíthatóság érdekében a háromóránként kiíratásra kerülő WRF adatokból napi csapadékösszegek kerültek számításra.

\section{Eredmények}

A 2. ábrán látható normált Taylor diagram (Taylor, 2001) a modell által szimulált és az E-OBS mérési adatbázisban található napi csapadékösszeg adatsorok között számolt alapvető statisztikai mutatókat jeleníti meg. Az adatokat a kiemelt érdeklődési területünkre (é. sz. $42^{\circ}-$ $52^{\circ}, \mathrm{k}$. h. $4^{\circ}-30^{\circ}$, vagyis a Kárpát-medencére és tágabb környezetére) értékeltük ki. A számításokat elvégeztük minden egyes rácspont figyelembe vételével, illetve az előbb említett területre mezőátlagot képezve. Az origóból sugárirányban kifelé húzott segédvonalak alapján leolvasható, hogy az öt különböző beállítású WRF szimulációból származó napi csapadékösszegek és a referencia-adatsor között számított Pearson-féle korrelációs együttható 0,8 körülinek adódott a mező átlagára számítva, és 0,5 körüli volt az összes rácspontot vizsgálva. A korrelációs együttható tekintetében a rácsfelbontás és a parametrizációs sémák megváltoztatása alig okozott különbségeket. A diagram x tengelyén, az 1 értéknél lévő, üres karikával jelölt ponttól vett távolság mutatja meg az adott szimuláció E-OBS adatbázishoz képest szá-

\footnotetext{
${ }^{11}$ Mellor-Yamada-Janjić planetáris határréteg séma

${ }^{12}$ European Centre for Medium-Range Weather Forecasts
} 
mított relatív átlagos négyzetes hibáját $\left(\mathrm{RMSE}^{13}\right)$. Ennek néhány kitüntetett értékét félkörívek jelölik. Mivel az adatok normáltak, ezért az RMSE számok a megfigyeléstöl vett relatív eltérést jelentik. Ezt elemezve elmondható, hogy a BMJ mély-konvekciós sémával készült futtatások jobban teljesítettek a többinél, ezzel szemben a G3DE cumulus parametrizáció használata rontotta a modellteljesítményt. Végezetül, ha a normalizált szórásokat is szemléljük - melyeket az origótól vett sugaras távolság ad meg - azt a következtetést is levonhatjuk, hogy a MYJ planetáris határréteg, illetve az Eta hasonlósági elven alapuló felszínközeli séma a napi csapadékösszeg realisztikusabb szimulációjához vezetett, mint a YSUMM5 hasonlósági parametrizáció párosítás. Megállapítható továbbá, hogy esetünkben a felbontás finomítása rontott a rácspontonkénti modelleredményeken, a mezőátlagok csekély mértékben javultak.

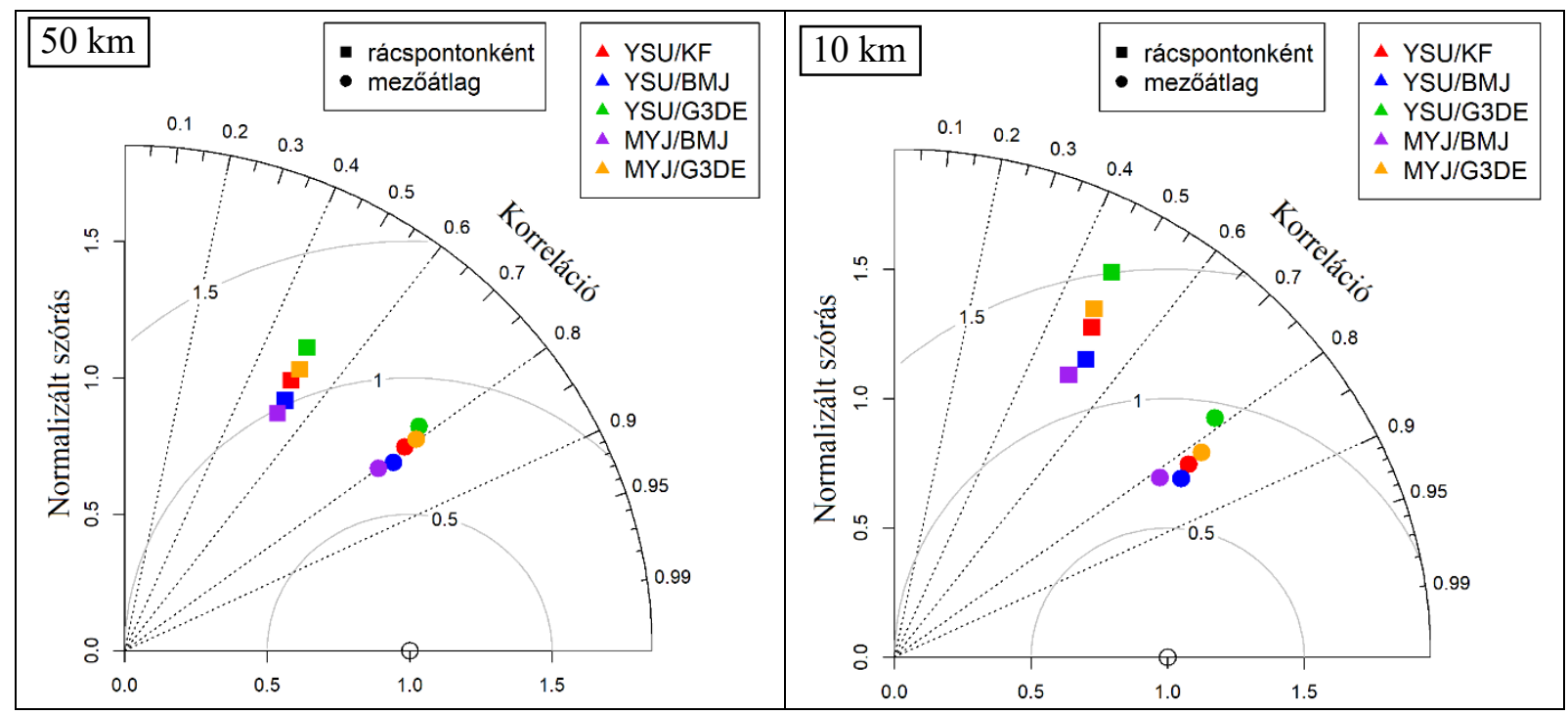

2. ábra: Taylor-diagram az öt különböző beállítással futtatott WRF modellszimuláció és az E-OBS adatbázis napi csapadékösszeg adatsoraira (2013),

50 km-es (balra) és 10 km-es (jobbra) rácstávolság esetén.

A 2013. évre vonatkozó, a vizsgálódási területre kiátlagolt éves csapadékösszeg (3.ábra) tekintetében az előbbiekhez hasonló következtetések vonhatók le. A durvább modellfelbontás jobb teljesítményhez vezetett. A leghatékonyabb mély-konvekciós sémának a BMJ bizonyult, míg a határréteg-felszín parametrizáció-kombinációk közül MYJ-Eta hasonlósági elvü párosítás produkált valóságosabb eredményt. Meg kell jegyezni azonban, hogy mind az öt konfigurációt felülbecslés jellemzi az E-OBS adatbázishoz képest.

A vizsgált területre átlagolt, 2013-as évre vonatkozó havi csapadékösszegekböl (4. ábra) látszik, hogy az öt futtatást túlnyomóan felülbecslés jellemzi a teljes időszakban. A nyári hónapokban és szeptemberben azonban a BMJ cumulus sémával, illetve az MYJ-Eta hasonlósági határréteg-felszínréteg parametrizációval, $50 \mathrm{~km}$-es felbontás mellett készült szimuláció (felső ábra) szinte pontosan visszaadja a megfigyelt értékeket. A $10 \mathrm{~km}$-es domainre vonatkozó diagramról (alsó ábra) hasonló következtetések vonhatók le, de általánosan nagyobb mértékü felülbecslésekkel, vagyis a finomabb felbontással rosszabb eredmények adódtak.

\footnotetext{
${ }^{13}$ Root Mean Square Error
} 


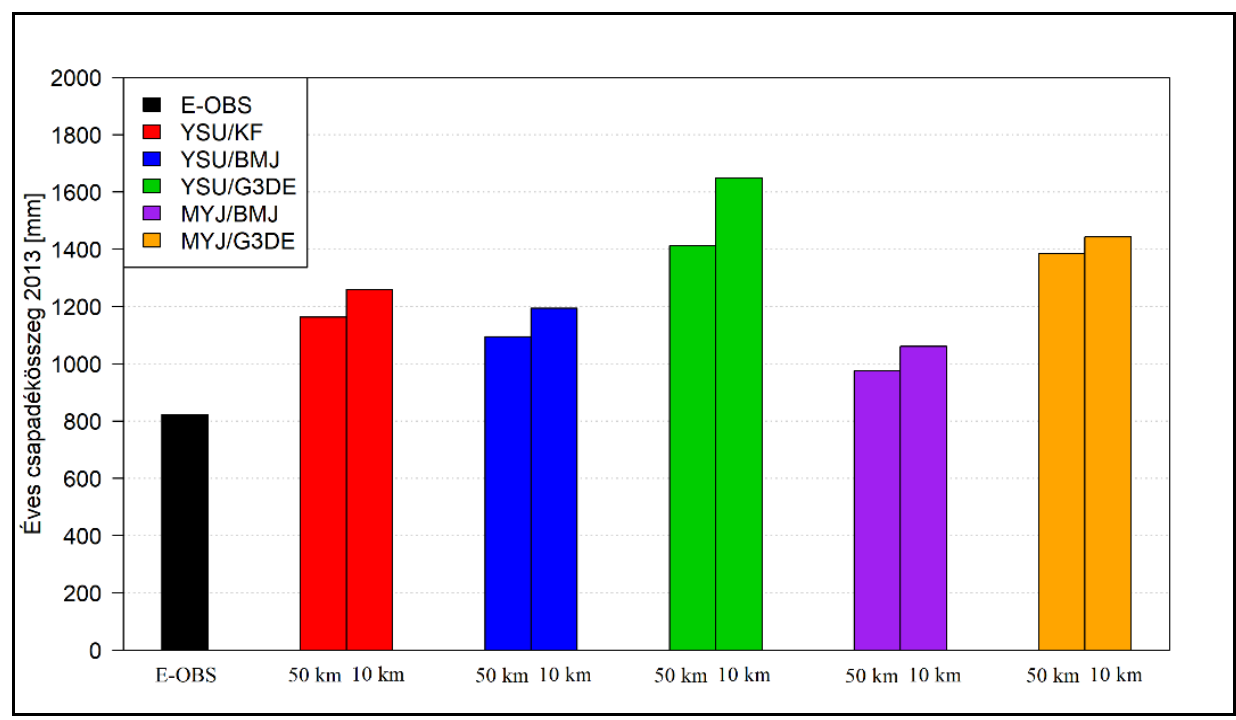

3. ábra: A 2013. évi csapadékösszeg az E-OBS mérési adatbázis, illetve az öt WRF modellszimuláció alapján, két különböző rácstávolság esetén.

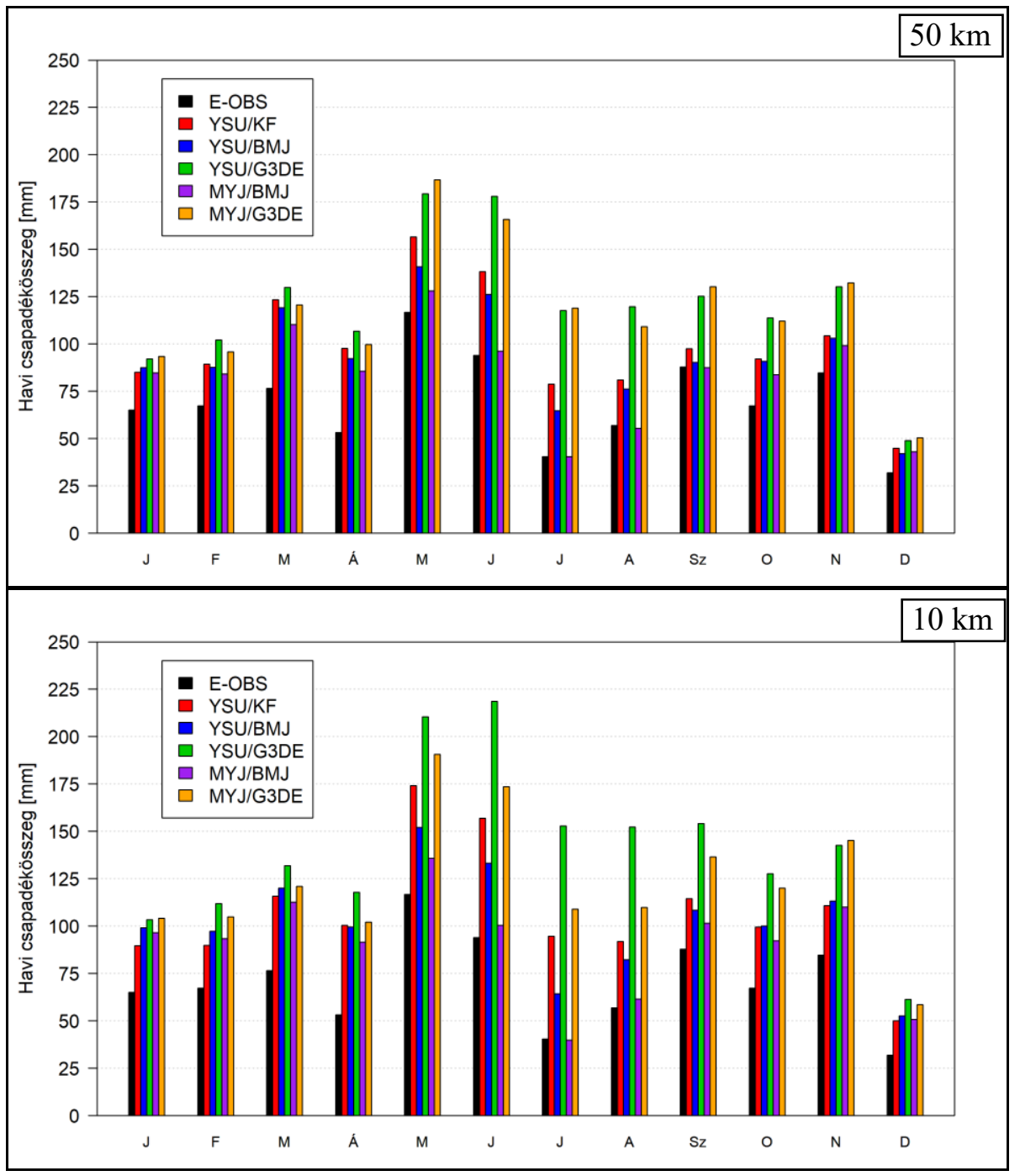

4. ábra: A 2013-as évre vonatkozó havi csapadékösszegek az E-OBS mérési adatbázis, illetve az öt WRF modellszimuláció alapján, $50 \mathrm{~km}$-es (fent) és $10 \mathrm{~km}$-es (lent) rácstávolság esetén. 
Az 5. ábra a legjobbnak értékelhető MYJ/BMJ (bal oldal), illetve a legkevésbé realisztikusnak mondható YSU/G3DE (jobb oldal) futtatások E-OBS mérési adatbázishoz képest vett éves csapadékösszeg-eltéréseinek mezőjét mutatja be, mind az $50 \mathrm{~km}$-es (fent), mind a $10 \mathrm{~km}$ es (lent) rácsfelbontás esetén. A YSU/G3DE szimuláció a teljes területen felülbecslést mutat, ráadásul nagy kiterjedésben (Kelet-Magyarországon és Romániában) jelentős, 120\%-ot meghaladó mértéküt. Ezzel szemben a MYJ/BMJ futtatás például Horvátország térségében és a Kárpátoktól délre alábecsül, vagyis a valóságosnál szárazabb viszonyokat produkál, és a nedves torzítás csak kis területen haladja meg a 120\%-ot. Szembetünő továbbá, hogy ezutóbbi szimuláció $10 \mathrm{~km}$-es felbontású (alsó ábrán látható) változata a hegységek vonulati mentén (Kárpátok, Dinári-hegység) jobban felülbecsül, mint az 50 km-es. A domborzati kényszerből keletkező csapadék felülbecslést már több vizsgálat is kimutatta (pl. Marteau et al., 2015). Ennek oka lehet a mérési adatbázis felbontásának problémája, amely különösen igaz az E-OBS adatbázis esetén erre a térségre (Haylock et al., 2008), illetve a vertikális sebesség túlbecslése a mély-konvekciós, illetve mikrofizikai sémák által.

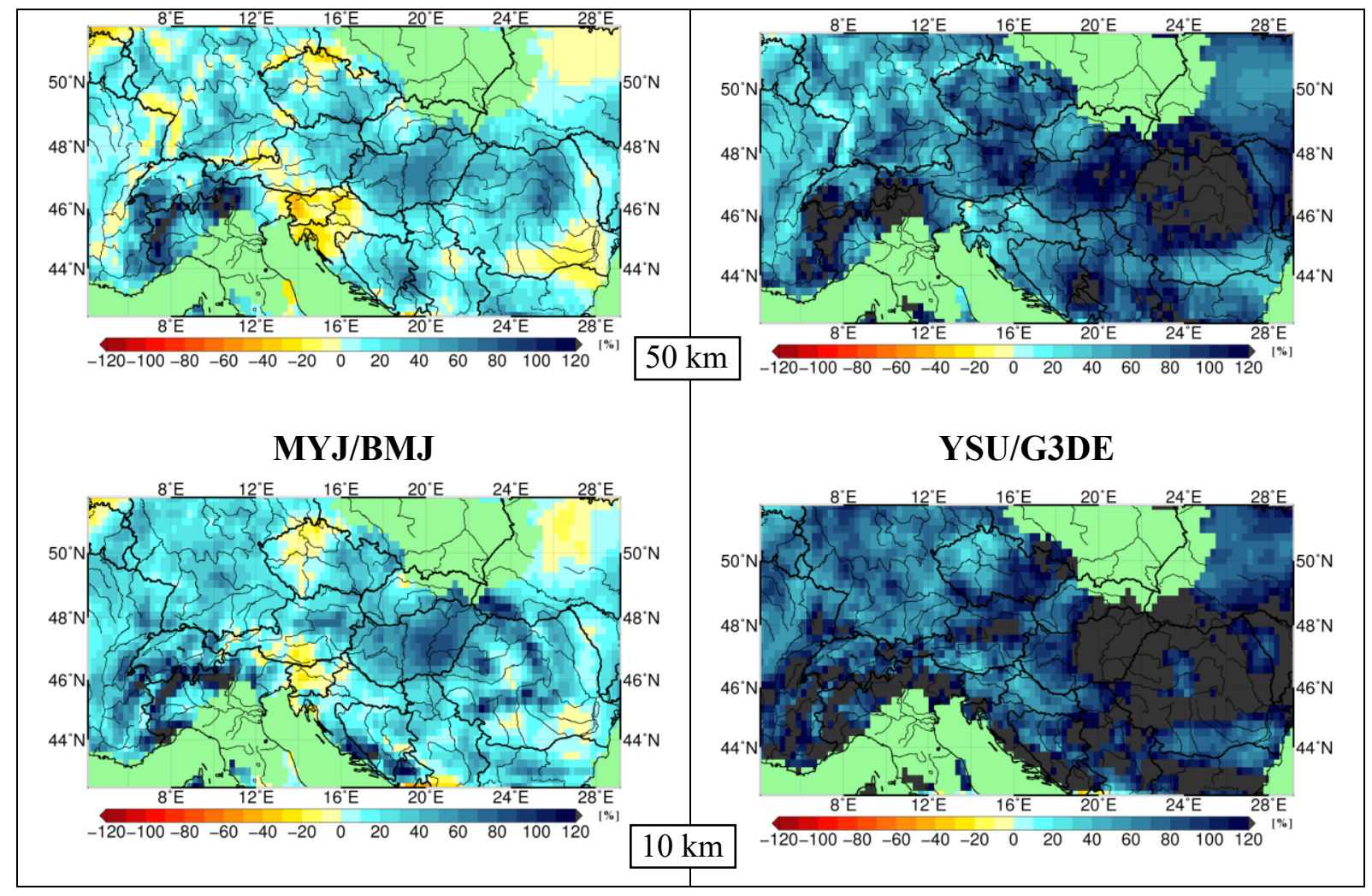

5. ábra: A legjobbnak (bal oldal) és a legrosszabbnak (jobb oldal) értékelhető

WRF szimulációból számított 2013. évi csapadékösszeg E-OBS mérési adatbázistól vett eltéréseinek mezője, $50 \mathrm{~km}$-es (fent) és $10 \mathrm{~km}$-es (lent) rácstávolság esetén.

\section{Összefoglalás}

Kutatásunk során a WRF-nek, mint regionális éghajlati modellnek az érzékenységvizsgálatát végeztük el. Öt különböző konfigurációval készítettünk szimulációkat az egyéves időszakra, melyek a mély-konvekciós (cumulus), valamint a planetáris határréteg-felszíni réteg parametrizációs sémákban tértek el egymástól. A futtatások során $50 \mathrm{~km}$-es és $10 \mathrm{~km}$-es horizontális felbontást egyaránt alkalmaztunk. A 2013-as év csapadékviszonyaira vonatkozó modelleredményeket ezután az E-OBS mérési adatokkal hasonlítottuk össze validáció céljából. 
Azt találtuk, hogy a Betts-Miller-Janjić cumulus séma, valamint a Mellor-Yamada-Janjić planetáris határréteg és az Eta hasonlósági elven alapuló felszíni réteg parametrizáció használata javította a modellteljesítményt a csapadék tekintetében. Szintén reálisabb eredményekre vezetett a durvább, $50 \mathrm{~km}$-es rácstávolság alkalmazása. A felbontás $10 \mathrm{~km}$-re való finomítása a hegyvidékeken nagyobb mértékü felülbecslést okozott. A Grell 3D Ensemble mélykonvekciós séma bizonyult a legkevésbé hatékonynak az éghajlati viszonyok elfogadható reprodukálására. Megállapítható, hogy a WRF - bár általános túlbecslés jellemzi - a nyári csapadék tekintetében nagyobb pontosságot mutat, mint az év más részeiben.

A munka folytatásaként fontosnak tartjuk további modellbeállítások tesztelését, különös figyelmet fordítva a planetáris határréteg sémákra. Szükséges továbbá a mikrofizikai parametrizáció konstans értékeinek felülvizsgálata és optimalizálása. Mivel éghajlati szimulációkról van szó, természetesen hosszabb távra vonatkozó modellfuttatások elvégzése indokolt.

\section{Hivatkozások}

Dudhia, J., 1989: Numerical study of convection observed during the winter monsoon experiment using a mesoscale two-dimensional model. J. Atmospheric Sci., 46: 3077-3107. https://doi.org/10.1175/1520-0469(1989)046<3077:NSOCOD>2.0.CO;2

Grell, G.A., Dévényi, D., 2002: A generalized approach to parameterizing convection combining ensemble and data assimilation techniques. Geophys. Res. Lett., 29(14): 381-38-4. https://doi.org/10.1029/2002GL015311

Haylock, M.R., Hofstra, N., Klein Tank, A.M.G., Klok, E.J., Jones, P.D., New, M., 2008: A European daily high-resolution gridded data set of surface temperature and precipitation for 1950-2006. J. Geophys. Res.: Atmospheres, 113(D20). https://doi.org/10.1029/2008JD010201

Hersbach, H., Dee, D., 2016: ERA5 reanalysis is in production. ECMWF Newsletter, No. 147, ECMWF, Reading, United Kingdom, 7.

Hong, S.Y., Noh, Y., Dudhia, J., 2006: A new vertical diffusion package with an explicit treatment of entrainment processes. Mon. Weather Rev., 134: 2318-2341. https://doi.org/10.1175/MWR3199.1

Janjić, Z.I., 1994: The step-mountain eta coordinate model: Further developments of the convection, viscosus sublayer, and turbulence closure scheme. Mon. Weather Rev., 122: 927-945. https://doi.org/10.1175/1520-0493(1994)122<0927:TSMECM>2.0.CO;2

Kain, J.S., 2004: The Kain-Fritsch convective parameterization: an update. J. App. Meteorol., 43: 170-181. https://doi.org/10.1175/1520-0450(2004)043<0170:TKCPAU >2.0.CO;2

Krüzselyi, I., Bartholy, J., Horányi, A., Pieczka, I., Pongrácz, R., Szabó, P., Szépszó, G., Torma, Cs., 2011: The future climate characteristics of the Carpathian Basin based on a regional climate model miniensemble. Adv. Sci. Res., 6: 69-73. https://doi.org/10.5194/asr$\underline{\text { 6-69-2011 }}$

Marteau, R., Richard, Y., Pohl, B., Chateau Smith, C., Castel, T., 2015: High-resolution rainfall variability simulated by the WRF RCM: application to eastern France. Clim. Dyn., 44: 1093-1107. https://doi.org/10.1007/s00382-014-2125-5

Mlawer, E.J., Taubman, S.J., Brown, P.D., Iacono, M.J., Clough, S.A., 1997: Radiative transfer for inhomogeneous atmospheres: RRTM, a validated correlated-k model for the longwave. J. Geophys. Res.: Atmospheres, 102(D14): 16663-16682. https://doi.org/10.1029/97JD00237

Niu, G.Y., Yang, Z.L., Mitchell, K.E., Chen, F., Ek, M.B., Barlage, M., Kumar, A., Manning, K., Niyogi, D., Rosero, E. and Tewari, M., 2011: The community Noah land surface model with multiparameterization options (Noah-MP): 1. Model description and evaluation with 
local-scale measurements. J. Geophys. Res.: Atmospheres, 116(D12). https://doi.org/10.1029/2010JD015139

Paulson, C.A., 1970: The mathematical representation of wind speed and temperature profiles in the unstable atmospheric surface layer. J. App. Meteorol., 9: 857-861. https://doi.org/10.1175/1520-0450(1970)009<0857:TMROWS >2.0.CO;2

Rummukainen, M., 2010: State-of-the-art with Regional Climate Models. Wiley Interdisciplinary Reviews, Clim. Change, 1: 82-96. https://doi.org/10.1002/wcc.8

Skamarock, W.C., Klemp, J.B., Dudhia, J., Gill, D.O., Barker, D.M., Duda, M.G., Huang, X.Y., Wang, W., Powers, J.G., 2008: A Description of the Advanced Research WRF Version 3. NCAR/TN-475+STR, NCAR Technical Note, $125 \mathrm{p}$.

Taylor, K.E., 2001: Summarizing multiple aspects of model performance in a single diagram. J. Geophys. Res., 106: 7183-7192. https://doi.org/10.1029/2000JD900719

Thompson, G., Eidhammer, T., 2014: A study of aerosol impacts on clouds and precipitation development in a large winter cyclone. J. Atmospheric Sci., 71(10): 3636-3658. https://doi.org/10.1175/JAS-D-13-0305.1

\section{ORCID}

Breuer H. (D) https://orcid.org/0000-0002-0271-095X 